\title{
Pengaruh Konsentrasi Air Rebusan Daun Melinjo (Gnetum Gnemon L.) Terhadap Total Mikroba Kerabang Dan Specific Gravity Telur Ayam Ras
}

\author{
The effect of concentration of melinjo (Gnetum Gnemon L.) Leaves booked water on total \\ microbills and specific gravity chicken eggs
}

\author{
Suharyanto ${ }^{1}$, Edi Soetrisno ${ }^{1}$, dan Riza Surya Islamiati ${ }^{1}$ \\ ${ }^{1}$ Jurusan Peternakan, Fakultas Pertanian, Universitas Bengkulu \\ Jalan Raya W. R. Supratman, Kandang Limun, Kota Bengkulu, 38371 \\ Corresponding e-mail: suharyanto@unib.ac.id
}

\begin{abstract}
This study aimed to determine the effect of soaking broiler eggs into boiled water with Melinjo (Gnetum gnemon L.) leaves with different concentrations on the total microbial shell and Specific Gravity of broiler eggs. This research was conducted at the Laboratory of Animal Husbandry, Department of Animal Husbandry, University of Bengkulu and UPTD Laboratory of Veterinary Public Health at the Department of Animal Husbandry and Animal Health of Bengkulu Province. The research design used was a completely randomized design (CRD) with 4 treatments and each treatment consisted of 4 replications. P0: Control chicken eggs without soaking in boiled water of melinjo leaves (ARDM). P1: (ARDM) 15\%. P2: (ARDM) 30\%. P3: (ARDM) 45\%. The variables observed in this study were the percentage change in egg weight, eggshell weight percentage, specific gravity and TPC (Total Plate Count) of broiler eggshells. The results showed that broiler eggs soaked with boiled water of melinjo leaves at a concentration of $15 \%$ $45 \%$ had a significant effect $(\mathrm{P}<0.05)$ on the percentage of egg weight loss on day 21 . However, it had no significant effect $(\mathrm{P}>0.05)$ on the percentage of shell weight, specific gravity and TPC (Total Plate Count) of broiler eggshells. Immersion of broiler eggs using boiled water of melinjo leaves was not able to reduce the number of microbes in the egg shell but was able to suppress the shrinkage of egg weight, shell weight and could maintain the specific gravity value up to 21 days of storage compared to eggs without soaking boiled water of melinjo leaves (control).
\end{abstract}

Keywords: broiler eggs, melinjo leaves, Specific gravity, TPC (Total Plate Count)

\begin{abstract}
ABSTRAK
Penelitian ini bertujuan untuk mengetahui pengaruh perendaman telur ayam ras ke dalam air rebusan daun Melinjo (Gnetum gnemon L.) dengan konsentrasi berbeda terhadap total mikroba kerabang dan Specific Gravity telur ayam ras. Penelitian ini dilaksanakan di Laboratorium Peternakan Jurusan Peternakan Universitas Bengkulu dan UPTD Laboratorium Kesmavet Dinas peternakan dan kesehatan hewan Provinsi Bengkulu. Rancangan penelitian yang digunakan adalah Rancangan Acak Lengkap (RAL) dengan 4 perlakukan dan setiap 1 perlakuan terdiri dari 4 ulangan. P0: Telur ayam ras Kontrol tanpa direndam air rebusan daun melinjo(ARDM). P1: (ARDM) 15\%. P2: (ARDM) 30\%. P3: (ARDM) 45\%. Variabel yang diamati pada penelitian ini adalah persentase perubahan berat telur, persentase berat kerabang telur, specifick gravity dan TPC (Total Plate Count) kerabang telur ayam ras. Hasil penelitian menunjukkan bahwa telur ayam ras yang direndam dengan air rebusan daun melinjo pada konsentrasi $15 \%-45 \%$ berpengaruh nyata $(\mathrm{P}<0,05)$ terhadap persentase penyusutan berat telur hari ke-21. Akan tetapi tidak berpengaruh nyata $(\mathrm{P}>0,05)$ terhadap persentase berat kerabang, specific gravity dan TPC (Total Plate Count) kerabang telur ayam ras. Perendaman telur ayam ras menggunakan air rebusan daun melinjo tidak mampu menurunkan jumlah mikroba pada kerabang telur tetapi mampu menekan penyusutan berat telur, berat kerabang dan dapat mempertahankan nilai specific gravity hingga penyimpana 21 hari dibanding dengan telur yang tanpa perendaman air rebusan daun melinjo (kontrol).
\end{abstract}

Kata Kunci: Telur ayam ras, Daun melinjo, Specific gravity, TPC (Total Plate Count) 


\section{PENDAHULUAN}

Telur merupakan produk peternakan yang mengandung nilai asam amino esensial yang dibutuhkan tubuh manusia. Karena memiliki kandungan gizi tinggi, telur mudah rusak akibat bakteri, antara lain Salmonella, bahan kimia dari limbah, dan benturan atau gesekan. Telur segar dengan mutu baik disimpan tidak lebih dari 10-14 hari. Apabila disimpan lebih dari waktu itu, telur akan rusak. Telur mengalami perubahan-perubahan ke arah kerusakan seperti terjadinya penguapan kadar air melalui pori-pori kulit telur yang berakibat kurangnya berat telur, perubahan komposisi kimia dan terjadinya pengenceran isi telur sehingga mempengaruhi kualitas dan kesegaran telur (Cornelia et al., 2014). Telur mudah mengalami penurunan kualitas baik kerusakan secara fisik, kimia maupun secara biologis.Kerusakan secara fisik, dan penguapan air dan gas-gas seperti karbondioksida (CO2), amonia (NH3), nitrogen (N2), dan hidrogen sulfida (H2S) dari dalam telur.Kualitas telur juga dapat dipengaruhi oleh lama penyimpanan, suhu,kelembaban relatif, dan kualitas kerabang telur (Jazil et al., 2013).

Permasalahannya ialah kerusakan pada telur secara biologis disebabkan oleh mikroorganisme, mikroorganisme yang dapat mencemari telur diantaranya adalah Salmonella sp, Stapylococcus aureus dan Escerechia coli. Dalam keadaan tertentu dan dalam jumlah yang melebihi batas, mikroorganisme yang terdapat dalam telur tersebut dapat menyebabkan keracunan bagi yang mengkonsumsinya (Chusniati et al., 2009).

Proses pencemaran mikroba juga dapat terjadi melalui pori-pori pada kulit telur. Jumlah Mikroba pada telur semakin meningkat sejalan dengan lamanya penyimpanan (Nurjanna, 2015). Pengawetan telur merupakan salah satu usaha untuk mencegah menurunnya kualitas telur. Salah satu upaya yang dapat dilakukan untuk menjaga kualitas telur dan memperpanjang masa simpan, yaitu dengan cara merendam telur segar dalam berbagai larutan seperti air kapur, larutan air garam, dan filtrat atau penyamak nabati yang mengandung tanin.

Pengukuran kualitas telur dapat dilakukan dengan menentukan nilai dari specific gravity telur. Specific gravity telur disebut juga dengan penentuan bobot jenis yaitu suatu cara untuk menentukan ketebalan kerabang dan mutu dari cangkang (Butcher, 1991).

Menurut hasil analisis Lestari et al. (2012) kandungan senyawa tanin daun melinjo adalah 4,55\%. Dengan adanya kandungan tanin pada daun melinjo maka mungkin saja daun melinjo dapat digunakan pada pengawetan telur ayam ras. Tanin akan bereaksi dengan protein yang terdapat pada kulit telur yang mempunyai sifat menyerupai kolagen kulit hewan sehingga terjadi proses penyamakan kulit berupa endapan berwarna coklat yang dapat menutup pori-pori kulit telur tersebut menjadi impermeable (tidak dapat tembus) terhadap gas dan udara dan penguapan air 
serta hilangnya karbondioksida pada kulit telur dapat dicegah sekecil mungkin (Karmila et al., 2008).

Menurut Santoso et al., (2008) melinjo memberikan efek yang baik sebagai pengawet makanan, dari inhibitor rasa dan peningkat rasa. Melinjo membuat langkah penting pada industri makanan yang tidak menggunakan bahan kimia sintetik. Daun melinjo (Gnetum gnemon L.) serta buahnya mengandung tanin, selain tanin daun melinjo juga mengandung saponin, flavonoida.

Selama ini Masyarakat pada umumnya hanya memanfaatkan daun melinjo (Gnetum gnemon L.) sebagai sayur yang dikonsumsi, mudah diperoleh dan harga yang relatif murah. Dengan dilaksanakannya penelitian ini diharapkan dengan memanfaatkan daun muda melinjo sebagai bahan coating atau penyamak pada telur ayam ras, akan memberikan nilai tambah dan dapat memperpanjang daya simpan telur segar.

Penelitian ini bertujuan untuk mengetahui pengaruh perendaman telur ayam ras ke dalam air rebusan daun melinjo (Gnetum gnemon L.) dengan konsentrasi 15\%, 30\% dan $45 \%$ terhadap total Mikroba Kerabang dan Specific Gravity telur ayam ras. Pada lama penyimpanan di suhu ruang penggunaan air rebusan daun melinjo (Gnetum gnemon L.) diduga dapat memperbaiki karakteristik mikroba kerabang dan nilai Specific Gravity kerabang telur ayam ras.

\section{MATERI DAN METODE}

\section{Materi}

Penelitian ini dilaksanakan pada bulan Desember 2020 dan Januari 2021 berlokasi di Laboratorium Peternakan Jurusan Peternakan Universitas Bengkulu dan UPTD Laboratorium Kesmavet Dinas peternakan dan kesehatan hewan Provinsi Bengkulu.

Alat yang digunakan dalam penelitian ini yaitu pisau, gunting, talenan, karung, timbangan biasa, timbangan digital, panci, kompor, saringan, toples, baskom, saringan, alat tulis, stopwatch, penggaris, egg tray, cawan porselin, gelas ukur, hygrometer, termometer, oven, tabung reaksi, cawan petri, batang pengaduk, pipet penghisap, lampu spritus, inkubator, autoclave, plastik steril, gelas baker, labu Erlenmeyer, plastic wrap, pengocok tabung (vortex), corong, aluminium foil, mikro tip, mikropipet.

Bahan-bahan yang digunakan pada penelitian ini yaitu, telur ayam ras,cangkang telur ayam ras, alkohol 70\%, media Plate Count Agar (PCA), Buffer Pepton Water (BPW), Aquadest, daun muda melinjo, tisu, kain lap, garam, kertas label. 


\section{Metode}

\section{Pengambilan Sampel}

Menyiapkan telur ayam ras yang diambil dari peternakan ayam ras di Provinsi Bengkulu. Telur yang digunakan berumur tidak lebih dari 24 jam dengan jumlah telur sebanyak 180 butir telur ayam ras. Kemudian telur dibersihkan dengan air hangat untuk menghilangkan kotoran dan bakteri-bakteri yang menempel pada kulit telur, kemuduan telur ditimbang. Serta menyiapkan daun melinjo yang nantinya akan direbus untuk diambil airnya digunakan dalam penelitian ini. Mempersiapkan alat yang akan digunakan dan membersihkan terlebih dahulu agar bersih dan nyaman untuk digunakan sehingga tidak menghambat dalam penelitian.

\section{Pembuatan Air rebusan Daun Melinjo (Gnetum gnemon L.)}

Daun melinjo yang digunakan dalam penelitian ini adalah daun melinjo muda sesuai dengan pernyataan Ummah (2010), dimana kandungan tanin terbanyak terdapat pada daun muda. Daun muda melinjo memiliki ciri-ciri berwarna hijau muda dengan tekstur lebih lembut dibandingkan daun melinjo yang lainnya dengan tangkai daun yang lembut biasanya daun muda melinjo terdapat di bagian pangkal daun sekitar 2-4 lembar daun paling pucuk yang termasuk daun muda. Daun melinjo di iris-iris kecil dengan ukuran $\pm 1 \mathrm{~cm}$ untuk mempermudah proses pengeringan daun supaya daun dapat kering secara merata. Kemudian daun dikeringkan (kering angin) terlebih dahulu hingga berat daun konstan sebelum direbus (Karmila et al., 2008). Dari uji coba pengeringan daun yang telah kami coba di dapatkan suhu penjemuran angin di dalam ruangan berkisar suhu $28-30^{\circ} \mathrm{C}$ dengan kelembapan berkisar $70 \%-80 \%$.

Konsentrasi daun melinjo yang digunakan pada penelitian ini adalah perbandingan $15 \%$ (b/v), 30\% (b/v) dan 45\% (b/v), berat daun melinjo yang di butuhkan yaitu sebanyak 450 gram, 900 gram dan 1.350 gram daun melinjo yang masing-masing direbus dalam $3000 \mathrm{ml}$ air. Selanjutnya untuk memperoleh zat tanin dari daun melinjo tersebut direbus selama 10 menit (Nugroho, 2008).

Suhu perebusan daun melinjo (Gnetum gnemon L.) berkisar 80-90 C, karena suhu yang optimal akan mengasilkan zat bioaktif yang terkandung dalam daun dan tidak merusaknya. Daun melinjo yang telah kering karena pengeringan angin dimasukan kedalam air panas ketika air sudah mencapai suhu $80-90^{\circ} \mathrm{C}$ dan pada suhu tersebut baru dihitung lama perebusan selama 10 menit. Menurut Karmila et al. (2008) tujuan dari perebusan daun melinjo (Gnetum gnemon L.) adalah untuk mempercepat larutnya tanin dalam air sehingga tanin yang diperoleh lebih banyak dan 
menghilangkan bakteri-bakteri yang ada dalam air. Setelah daun melinjo direbus kemudian airnya disaring dan didinginkan. Suhu dingin untuk air rebusan adalah berkisar suhu ruang $28-30^{\circ} \mathrm{C}$.

\section{Perendaman Telur dengan Air rebusan Daun Melinjo (Gnetum gnemon L.)}

Air rebusan daun melinjo (Gnetum gnemon L.) didinginkan terlebih dahulu sampai suhu $28-30^{\circ} \mathrm{C}$ yang merupakan suhu ruang. Total telur yang digunakan Sebanyak 180 butir telur ayam ras yang terbagi menjadi 4 perlakuan dengan 4 ulangan, setiap perlakuan terdiri dari 4 butir telur. Sebanyak 45 butir telur direndam selama 24 jam didalam toples berukuran 10 liter dengan volume air rebusan daun melinjo sebanyak $3000 \mathrm{ml}$. Setelah 24 jam perendaman kemudian telur di tiriskan dan dikeringkan dengan menggunakan tissu atau kain lap dan ditaruh pada egg tray dan diberi label kemudia disimpan pada suhu ruang $28-30^{\circ} \mathrm{C}$. Pengukuran/pengujian dan pengamatan dilakukan pada hari ke 14 dan ke 21 hari. Telur ayam ras dimasukan kedalam wadah ditutup untuk menghindari kontaminasi dengan udara luar sehingga dapat memaksimalkan terjadinya reaksi penyamakan (Karmilla, et al., 2008).

\section{Rancangan Penelitian}

Rancangan penelitian yang akan digunakan adalah Rancangan Acak Lengkap (RAL) dengan 4 perlakukan dan setiap 1 perlakuan terdiri dari 4 ulangan. Masing-masing perlakuan terdiri dari 4 butir telur ayam segar.

Level konsentrasi tiap perlakukan penelitian sebagai berikut:

P0 Telur = Air rebusan Daun Melinjo (Gnetum gnemon L.) $0 \%$
P1 Telur = Air rebusan Daun Melinjo (Gnetum gnemon L.) $15 \%$
P2 Telur = Air rebusan Daun Melinjo (Gnetum gnemon L.) $30 \%$
P3 Telur = Air rebusan Daun Melinjo (Gnetum gnemon L.) $45 \%$

\section{Variabel yang diamati}

\section{Persentase Penyusutan Berat Telur}

Penyusutan berat telur merupakan penurunan berat telur dari berat awal dikarenakan pengaruh beberapa faktor yang menyebabkan terjadinya penyusutan. Penyusutan berat telur akan bertambah besar dengan bertambahnya umur simpan sampai batas tertentu dan selanjutnya berat telur akan relatif konstan (Romanoff dan Romanoff, 1963). Menurut Sudaryani (2003) penyusutan berat telur dapat diperoleh dari selisi berat awal dengan berat akhir sesuai umur penyimpanan atau susut berat. Rumus yang digunakan untuk menghitung penyusutan berat telur ayam ras menurut Asjayani (2014), yaitu:

$$
\text { Rumus susut berat telur }=\frac{\text { Berat awal }(\mathrm{g})-\text { Berat akhir }(\mathrm{g})}{\text { Berat awal }(\mathrm{g})} \times 100 \%
$$




\section{Persentase Berat Kerabang}

Berat kerabang diukur dengan melakukan penimbangan cangkang telur menggunakan timbangan digital dengan satuan gram, setiap kerabang telur ditimbang.

\section{Rumus Persentase Berat Kerabang $=$ Berat kerabang telur $(\mathrm{g}) \times 100 \%$ \\ Berat telur (g)}

\section{Specific gravity}

Pengukuran kualitas telur dapat dilakukan dengan menentukan nilai dari Specific Gravity telur. Specific gravity merupakan nilai menunjukkan berat jenis telur, telur segar memiliki nilai specific gravity yang lebih tinggi dibandingkan telur yang sudah tersimpan lama. Pengukuran Specific gravity adalah perbandingan berat suatu benda dengan berat volume air yang sama (Butcher dan Miles, 2004). Penentuan specific gravity merupakan metode untuk menentukan ketebalan telur dan kualitas kerabang.

Nilai standar specific gravity untuk ayam tipe petelur adalah 1,075 (Butcher, 1991). Telur dimasukkan ke dalam ember yang berisi larutan garam dengan beberapa tingkat keenceran dan diurutkan mulai dari larutan garam yang terencer (Specific gravity nya terendah), Specific gravity ditentukan berdasarkan perbandingan larutan garam yang menyebabkan telur mengambang. Perbandingan garam dan air untuk penentuan specific gravity dapat dilhat pada Tabel 1.

Table 1. Perbandingan air dan garam yang dibutuhkan untuk mendapatkan nilai specific gravity tertentu.

\begin{tabular}{ccc}
\hline Air $(\ell)$ & Garam $(\mathrm{g})$ & Nilai specific gravity telur \\
\hline 3 & 276 & 1,060 \\
3 & 298 & 1,065 \\
3 & 320 & 1,070 \\
3 & 342 & 1,075 \\
3 & 365 & 1,080 \\
3 & 390 & 1,085 \\
3 & 414 & 1,090 \\
3 & 438 & 1,095 \\
3 & 462 & 1,100 \\
\hline
\end{tabular}

*Sumber: Butcher, 1991

Cara pengukuran;

- Telur dimasukkan ke dalam keranjang berongga

- Selanjutnya keranjang yg berisi telur dimasukkan ke dalam ember yg berisi larutan garam dengan beberapa tingkat keenceran dan diurutkan mulai dari larutan garam yang terencer (specific gravity nya terendah)

- Pada larutan dengan specific grafity berapakah telur mulai mengambang.

81 Pengaruh Konsentrasi Air Rebusan ... 


\section{TPC (Total Plate Count) Kerabang}

Total Plate Count (TPC ) untuk telur ayam konsumsi adalah $1 \times 10^{5} \mathrm{cfu} / \mathrm{g}$. Tahapan pengujian ini adalah persiapan sampel, penghitungan jumlah koloni dan interpretasi hasil. Cangkang telur ditimbang sebanyak 5 gram kemudian digerus terlebih dahulu dan diencerkan dengan aquades dengan perbandingan 1:1 yang kemudian dihomogenkan. Cangkang telur yang sudah homogen dilakukan pengenceran, sampel dimasukkan ke dalam tabung reaksi yang berisi $45 \mathrm{ml}$ larutan BPW 0,1\% steril kemudian homogenkan dengan vortex selama 1-2 menit untuk mendapatkan pengenceran $\left(10^{-1}\right)$. Pengenceran berikutnya $1 \mathrm{ml}$ suspensi pengenceran dari tabung reaksi $\left(10^{-1}\right)$ dimasukkan ke tabung reaksi yang berisi larutan $9 \mathrm{ml}$ BPW untuk mendapatkan pengenceran $\left(10^{-2}\right)$. Pengenceran $\left(10^{-3}, 10^{-4}, 10^{-5}\right.$ dan $\left.10^{-6}\right)$ dan seterusnya dibuat dengan cara yang sama seperti sebelumnya.Pengujian kualitas mikrobiologi telur dengan metode Total Plate Count (TPC) (SNI 2897 : 2008). Memasukkan sebanyak $1 \mathrm{ml}$ suspensi dari setiap sampel pengenceran kedalam cawan petri secara duplo. Menambahkan 15-20 ml Plate Count Agar (PCA) yang sudah didinginkan hingga temperatur $45^{\circ} \mathrm{C} \pm 1^{\circ} \mathrm{C}$ pada masing-masing cawan yang sudah berisi suspensi. Supaya larutan sampel dan media PCA tercampur seluruhnya, lakukan pemutaran cawan ke depan dan ke belakang atau membentuk angka delapan dan diamkan sampai menjadi padat. Cawan petri dimasukkan ke dalam inkubator dengan posisi terbalik pada suhu $34^{\circ} \mathrm{C}$ sampai dengan $36^{\circ} \mathrm{C}$ selama 24 jam sampai dengan 48 jam. Jumlah koloni yang tumbuh dihitung pada setiap seri pengenceran kecuali cawan petri yang berisi koloni menyebar (spreader colonies). Cawan yang dipilih yaitu cawan yang mempunyai jumlah koloni 25 sampai dengan 250. Penghitungan jumlah koloni menggunakan alat bantu hitung colony counter, setelah pemilihan cawan akan dilakukan intepretasi hasil.

Cara perhitungan jumlah cemaran mikrob yaitu:

\section{Jumlah bakteri $=$ Rata-rata jumlah koloni $\times$ Faktor pengencer}

\section{Analisis Data}

Data yang diperoleh dianalisis dengan ANOVA ( Analysis of Variance ). Apabila terdapat perbedaan nyata $(\mathrm{P}<0,05)$ terhadap perlakuankan menggunakan uji lanjut menggunakan DMRT (Duncan Multiple Range Test). Selang Kepercayaan yang digunakan 95\%.

\section{HASIL DAN PEMBAHASAN}

\section{Persentase Penyusutan Berat Telur}

Evaporasi air dan gas $\mathrm{CO}_{2}$ dapat terjadi terhadapat telur segar yang disimpan pada suhu ruang, sebagai kegiatan respirasi yang berlangsung selama penyimpanan sehingga dapat menurunkan berat telur. Hasil penelitian penyusutan berat telur ayam ras yang direndam dengan 
air rebusan daun melinjo (ARDM) pada konsentrasi 15\%, 30\%, 45\% dan telur yang tidak direndam (kontrol) pada penyimpanan suhu ruang selama 14 dan 21 hari dengan rata-rata nilai dapat dilihat pada Tabel 2.

Table 2. Rata-rata persentase penyusustan berat telur (\%) dan persentase berat kerabang telur ayam ras (\%) yang direndam air rebusan daun melinjo dengan konsentrasi yang berbeda dan Lama Penyimpanan.

\begin{tabular}{cccccc}
\hline \multirow{2}{*}{ Parameter } & \multirow{2}{*}{ Pengamatan } & \multicolumn{4}{c}{ Perlakuan } \\
\cline { 3 - 6 } & & P0 & P1 & P2 & P3 \\
\hline \multirow{2}{*}{ Penyusutan B. Telur (\%) } & Hari ke-14 & $1,04 \pm 0,15$ & $1,23 \pm 0,20$ & $1,22 \pm 0,05$ & $1,34 \pm 0,22$ \\
& Hari ke-21 & $1,79 \pm 0,13^{\mathrm{a}}$ & $1,38 \pm 0,20^{\mathrm{b}}$ & $1,61 \pm 0,06^{\mathrm{ab}}$ & $1,69 \pm 0,19^{\mathrm{ab}}$ \\
\hline \multirow{2}{*}{ B.Kerabang (\%) } & Hari ke-14 & $0,11 \pm 0,002$ & $0,11 \pm 0,001$ & $0,11 \pm 0,004$ & $0,11 \pm 0,001$ \\
& Hari ke-21 & $0,10 \pm 0,006$ & $0,11 \pm 0,003$ & $0,10 \pm 0,002$ & $0,10 \pm 0,001$ \\
\hline
\end{tabular}

Keterangan: P0: Kontrol, P1: 15\% Air rebusan daun melinjo, P2: 30\% Air rebusan daun melinjo, P3: 45\% Air rebusan daun melinjo. Superscript a-c berbeda pada baris yang sama menunjukkan perbedaan yang nyata penyimpanan 21 hari $(\mathrm{P}<0,05)$.

Pada Tabel 2 terlihat bahwa penyimpanan hari ke-14 dan hari ke-21 terjadi penyusutan berat telur pada masing-masing perlakuan yaitu P0 1,04\% - 1,79\%, P1 1,23\% - 1,38\%, P2 1,22\% 1,61\% dan P3 1,34\% - 1,69\%. Semakin lama penyimpanan telur ayam ras maka nilai penyusutan berat telur semakin meningkat. Berdasarkan Tabel 2 dapat dilihat bahwa persentase penyusutan berat telur semakin meningkat pada masing-masing perlakuan. Rata-rata persentase penyusutan berat telur pada penyimpanan hari ke-14 yaitu 1,21\% dan pada hari ke-21 yaitu 1,62\% data ini lebih kecil dibandingkan data penelitian Andi (2014) dengan menggunakan ekstrak daun melinjo pada telur itik, pada lama penyimpanan 14 hari penyusutan rata-rata 2,04\% dan pada penyimpanan 21 hari rata-rata 3,23\%. Data ini menunjukkan bahwa penggunaan (ARDM) pada telur ayam ras lebih baik menekan penyusutan berat telur dibandingkan menggunakan telur itik.

Hasil analisis varian (ANOVA) menunjukkan bahwa lama penyimpanan telur ayam ras yang diberi perlakuan konsentrasi (ARDM) yang berbeda berpengaruh tidak nyata $(\mathrm{P}>0,05)$ terhadap persentase penyusutan berat telur ayam ras pada penyimpanan hari ke-14. Sedangkan pada penyimpanan hari ke-21 hasil analisis varian (ANOVA) berpengaruh nyata $(\mathrm{P}<0,05)$ terhadap persentase penyusutan berat telur ayam ras pada penyimpanan hari ke-21, sehingga dilanjutkan degan uji DMRT menunjukkan bahwa P0, P2 dan P3 tidak berbeda nyata, sementara P0 berbeda nyata dengan P1. Peningkatan penyusutan berat telur diduga terjadi karena penguapan didalam telur dan pengaruh suhu yang tinggi selama penyimpanan, serta kelembaban udara yang rendah akan mempercepat penguapan air dari dalam telur. Suhu selama penyimpanan berkisar $26^{\circ} \mathrm{C}-29^{\circ} \mathrm{C}$ dengan kelembaban berkisar $70 \%$ - 90\% suhu dan kelembaban ini cukup tinggi, hal ini dapat menyebabkan penurunan berat telur semakin cepat. Menurut Yuwanta (2010), yang 
menyatakan bahwa pada suhu penyimpanan $25^{\circ} \mathrm{C}$ dengan kelembaban relatif $70 \%$ akan menyebabkan telur kehilangan berat sebesar sekitar 0,8 gram setiap minggu setiap butirnya. Ratarata persentase penyusutan berat telur yang diperoleh dari lama penyimpanan menunjukkan bahwa semakin lama penyimpanan maka penyusutan berat telur semakin meningkat. Hal ini sesuai dengan pendapat Hardini (2000), yang menyatakan bahwa semakin lama umur telur maka terjadi penurunan isi telur karena proses evaporasi air dari dalam telur sehingga berat telur dapat berkurang.

\subsection{Persentase Berat Kerabang}

Hasil analisis varian (ANOVA) yang diperoleh menunjukkan bahwa telur yang diberi perlakuan konsentrasi air rebusan daun melinjo yang berbeda pada penyimpanan hari ke-14 dan hari ke-21 berpengaruh tidak nyata $(\mathrm{P}>0,05)$ terhadap persentase berat kerabang hari ke-14 dan hari ke-21. Rataan persentase berat kerabang adalah $11 \%$ pada penyimpanan hari ke-14 dan $10 \%$ pada penyimpanan hari ke-21. Bell dan Weaver (2002) menyatakan bahwa persentase berat kerabang telur memiliki kisaran angka $10-12 \%$ dari berat telur. Hal ini menunjukkan bahwa perlakuan konsentrasi air rebusan daun melinjo mampu mempertahankan persentase berat kerabang hingga penyimpanan 21 hari. Tanin yang berperan sebagai penyamak kulit telur dapat memperpanjang umur simpan telur. Tanin akan bereaksi dengan cara membuat protein di permukaan kulit telur menggumpal dan menutupi pori-pori sehingga dapat mencegah terjadinya penguapan, mencegah hilangnya $\mathrm{CO}_{2}$ dan mencegah masuknya mikroorganisme sehingga kualitas telur dapat terjaga (Karmila et al., 2010).

\subsection{Specific gravity}

Table 3. Rata-rata nilai Specific gravity (g) telur ayam ras yang direndam air rebusan Daun Melinjodengan konsentrasi yang berbeda dan Lama Penyimpanan.

\begin{tabular}{cccccc}
\hline \multirow{2}{*}{ Parameter } & \multirow{2}{*}{ Pengamatan } & \multicolumn{4}{c}{ Perlakuan } \\
\cline { 3 - 6 } & & P0 & P1 & P2 & P3 \\
\hline \multirow{2}{*}{ Specific gravity (g) } & Hari ke-14 & $1,08 \pm 0,004$ & $1,08 \pm 0,007$ & $1,08 \pm 0,000$ & $1,09 \pm 0,000$ \\
& Hari ke-21 & $1,07 \pm 0,011$ & $1,08 \pm 0,000$ & $1,08 \pm 0,011$ & $1,07 \pm 0,004$ \\
\hline
\end{tabular}

Keterangan: P0: Kontrol, P1: 15\% Air rebusan daun melinjo, P2: 30\% Air rebusan daun melinjo, P3: 45\% Air rebusan daun melinjo.

Hasi penelitian menunjukkan bahwa rata-rata nilai Specific gravity telur ayam ras penyimpanan hari ke-14 sebesar 1,08 pada perlakuan P0, P1 dan P2 sedangkan pada P3 sebesar 1,09. Nilai Specific gravity rata-rata pada penyimpanan hari ke-21 sebesar 1,07 pada perlakuan P0 dan P3 sedangkan pada P1 dan P2 sebesar 1,08. Nilai standar specific gravity untuk ayam tipe petelur adalah 1,075 (Butcher, 1991). Hasil analisi yang diperoleh menunjukkan bahwa telur ayam 
ras yang diberi perlakuan konsentrasi air rebusan daun melinjo yang berbeda pada penyimpanan hari ke-14 dan hari ke-21 berpengaruh tidak nyata $(\mathrm{P}>0,05)$ terhadap Specific gravity hari ke-14 dan hari ke-21. Hal ini menunjukkan bahwa telur mempunyai kualitas yang masih baik pada pada hari ke-14 sedangkan pada hari ke-21 pada P0 dan P3 nilai Specific gravity telur sedikit menurun dibawah standar di bandingkan dengan penyimpanan hari ke-14. Hal ini diduga karena proses penyamakan pada konsntrasi 15\%-30\% sudah maksimal dapat menutup pori-pori telur sehingga dapat menekan penguapan telur dan pembesaran rongga udara dapat diminimalisir. Sesuai dengan pendapat Karmila et al., (2008) yang menyatakan bahwa Tanin akan bereaksi dengan protein yang terdapat pada kulit telur yang mempunyai sifat menyerupai kolagen kulit hewan sehingga terjadi proses penyamakan kulit berupa endapan berwarna coklat yang dapat menutup pori-pori kulit telur tersebut menjadi impermeable (tidak dapat tembus) terhadap gas dan udara dan penguapan air serta hilangnya karbondioksida pada kulit telur dapat dicegah sekecil mungkin.

\subsection{TPC (Total Plate Count) Kerabang}

Table 4. Rata-rata TPC (Total Plate Count) kerabang telur ayam ras yang direndam air rebusan Daun Melinjo dengan konsentrasi yang berbeda dan lama penyimpanan.

\begin{tabular}{cccccc}
\hline \multirow{2}{*}{ Parameter } & \multirow{2}{*}{ Pengamatan } & \multicolumn{4}{c}{ Perlakuan } \\
\cline { 3 - 6 } & & P0 & P1 & P2 & P3 \\
\hline \multirow{2}{*}{ Log CFU/g Kerabang } & Hari ke-14 & $4,95 \pm 0,05$ & $5,98 \pm 0,27$ & $5,67 \pm 1,08$ & $5,23 \pm 0,59$ \\
& Hari ke-21 & $5,37 \pm 0,13$ & $6,20 \pm 0,55$ & $6,02 \pm 0,96$ & $5,87 \pm 0,58$
\end{tabular}

Keterangan: P0: Kontrol, P1: 15\% Air rebusan daun melinjo, P2: 30\% Air rebusan daun melinjo, P3: 45\% Air rebusan daun melinjo.

Rataan menunjukkan bahwa perlakuan total plate count yang dilakukan pada sampel telur ayam yang diberi perlakuan konsentrasi air rebusan daun melinjo yang berbeda dengan pengamatan hari ke-14, pada P0 yaitu 4,95 (Log CFU/g), pada P1 yaitu 5,98 (Log CFU/g) mengalami peningkatan jumlah dengan selisih 1,03 (Log CFU/gr), pada P2 yaitu 5,67 (Log CFU/g) mengalami penurunan jumlah dengan selisih 0,31, dan pada P3 yaitu 5,23 (Log CFU/g) mengalami penurunan jumlah dengan selisih 0,44 . Hasil total plate count hari ke-14 total mikroba mengalami kenaikan pada P1, sedangkan pada P2 dan P3 ada sedikit penurunan total mikroba.

Rataan total plate count penyimpanan hari ke-21 pada P0 yaitu 5,37 (Log CFU/g), P1 yaitu 6,20 (Log CFU/g), P2 yaitu 6,02 (Log CFU/g), dan P3 yaitu 5,87 (Log CFU/g). Total cemaran mikroba pada hari ke-21 mengalami peningkatan dibandingkan dengan hari ke-14. Jika dilihat pada masing-masing perlakuan pada konsentrasi (ARDM) 15\% - 45\% terdapat penurunan total mikroba walaupun tidak berbedanyata. Hal ini bisa saja terjadi karena faktor lingkungan sekitar seperti suhu dan kelembaban yang mempengaruhu pertumbuhan mikroba pada kerabang 
telur ayam ras. Telur yang di beri perlakuan menghasilkan total mikroba yang lebih banyak dibandingkan dengan telur tanpa perlakuan. Hal ini dapat terjadi karena pada proses penelitian pada telur tanpa perlakuan P0 (kontrol) dalam keadaan kering sedangkan telur yang diberi perlakuan P1, P2 dan P3 di rendam selama 24 jam di dalam air rebusan daun melinjo yang menyebabkan kerabang telur menjadi basah yang mempermudah mikroba dapat berkembang lebih cepat di kerabang telur. Kerabang telur mendapatkan cemaran mikroba pertama kali saat bergerak keluar melalui kloaka. Cemaran pada telur kemudian akan bertambah dari lingkungan terutama akibat kontak dengan bidang permukaan yang memiliki cemaran mikrob. Terdapat variasi jumlah cemaran mikrob yang terdapat pada permukaan kerabang telur mulai dari hanya sejumlah ratusan hingga jutaan mikrob pada setiap kerabang telur (Pui et al., 2011). Total plate count kerabang telur pada penyimpanan hari ke-14 dan 21 melebihi standar total plate count untuk telur ayam konsumsi. Berdasarkan SNI 3926 (2008), TPC untuk telur ayam konsumsi adalah 1x105 CFU/g atau 5 (Log CFU/g). Jumlah bakteri pada telur semakin meningkat sejalan dengan lama penyimpanan (Nurjanna, 2015). Menurut Keswandani (1996), proses pemasakkan dapat menurunkan cemaran mikroba menjadi $1,0 \times 10^{1} \mathrm{CFU} / \mathrm{g}$. Maka dari itu ada baiknya saat mengkonsumsi telur dalam keadaan matang sempurna untuk menurunkan jumlah bakteri sebelum telur tersebut dikonsumsi.

\section{KESIMPULAN}

Perendaman telur ayam ras menggunakan air rebusan daun melinjo (Gnetum gnemon L.) tidak mampu menurunkan jumlah mikroba pada kerabang telur tetapi pada konsentrasi $15 \%-45 \%$ perendaman dapat menekan penyusutan berat telur, berat kerabang dan dapat mempertahankan specific gravity hingga penyimpana 21 hari dibanding dengan telur yang tanpa perendaman air rebusan daun melinjo (kontrol).

\section{DAFTAR PUSTAKA}

Asjayani, Rani. 2014. Aplikasi Ekstrak Daun Enceng Gondok (Eichornia crassipes) pada level dan Lama Simpan terhadap Kualitas Telur Ayam Ras. Skripsi.Universitas Hassanudin.Makasar.

M.N., Andi. 2014. Pengaruh Level Ekstrak Daun Melinjo (Gnetum gnemon Linn) dan Lama Penyimpan yang Berbeda terhadap Kualitas Telur Itik. Skripsi Universitas Hasanuddin . Makasar

Badan Standar Nasional Indonesia (BSNI), 2008, Metode Pengujian Cemaran Mikroba dalam Daging, Telur dan Susu, serta Hasil Olahannya, SNI 2897-2008, Badan Standarisasi Nasional Indonesia, Jakarta

Badan Standar Nasional Indonesia nomor 01-3926-2008 Telur Ayam Konsumsi. Badan Standar Nasional. Jakarta. 
Bell, D. and W.D. Weaver. 2002. Commersial Chicken Meat and Egg Production. 5th Ed. Springer Science Business Media. Inc. Spring steet, New York.

Butcher, Gary D and RD. Miles. 2004. Egg Specific Gravity Designing a Monitoring Program. University of Florida. Florida.

Butcher, G.D. and Miles D. R. 1991. Egg Specific gravity-Designing A Monitoring program. Institute of Food and Agricultural Science.Florida.www.pjbs.org. Diakses tanggal 28 Maret 2021.

Chusniati, S., R.N. Budiono, dan R. Kurnijasanti. 2009. Deteksi Salmonella sp pada telur ayam buras yang dijual sebagai campuran jamu di kecamatan sidoarjo. Journal of Poultry Diseases. 2(1):20-23.

Cornelia, A., I. K. Suada, M. D. Rudyanto. 2014. Perbedaan Daya Simpan Telur Ayam Ras yang Dicelupkan dan Tanpa Dicelupkan Larutan Kulit Manggis. Indonesia Medicus Veterinus 3(2): 112-119.

Dewan Standardisasi Nasional (DSN). 1992. SNI 01-2897-1992. Metode PengujianCemaran Mikroba. Jakarta: Standar Nasional Indonesia.

Fibrianti, S.M., I. K. Suada, M. D. Rudyanto.2012.Kualitas Telur Ayam Konsumsi yang dibersihkan dan tanpa dibersihkan Selama Penyimpanan Suhu Kamar .Indonesia Medicus Veterinus 1(3):408 416.

Hardini. 2000. Pengaruh Suhu dan Lama Penyimpanan Telur Konsumsi dan Telur Biologis Terhadap Kualitas Interior Telur Ayam Kampung. FMIPA Universitas Terbuka

Jazil, N., A. Hintono, S. Mulyani.2013.Penurunan Kualitas Telur Ayam Ras dengan Intensitas Warna coklat kerabang berbeda selama penyimpanan.Jurnal Aplikasi Teknologi Pangan 1(2): 43-47.

Karmila.,M.,Maryati.,Jusmawati. 2008. Pemanfaatan Daun Jambu Biji (Psidium guajava L.),SebagaiAlternatif Pengawetan Telur Ayam Ras. FMIPA.UNM. Makassar.

Keswandani, R. 1996. Identifikasi titik pengendalian kritis pengolahan produk daging dan ikan dari industri jasa boga golongan A2 terhadap cemaran bakteri Salmonella sp. Skripsi Jurusan Pengolahan Hasil Pertanian, Fakultas Teknologi Pertanian, Universitas Gadjah Mada, Yogyakarta. $96 \mathrm{hlm}$

Lestari S, Malaka R, Garantjang S. 2012. Pengawetan Telur Dengan Perendaman Ekstrak Daun Melinjo (Gnetum Gnemon Linn). J. Sains \& Teknologi 13(2) : 184 - 189

Nugroho. 2008. Keperawatan Gerontik. Jakarta: Buku Kedokteran EGC.

Nurjanna, S. 2015. Kontaminasi bakteri telur ayam ras yang di pelihara dengan sistem pemeliharaan intensif dan free range dengan waktu pemberian naungan alami berbeda. Skripsi. Fakultas Perternakan, Universitas Hasanuddin, Makassar.

Pui, C.F., Wong W, Chai L.C, Tunung R, Jeyaletchumi P, Noor H.M.S, Ubong, A, Farinazleen M.G, Cheah Y.K, Son R. 2011. Salmonella: A foodborne pathogen. Int Food Res J. 18:465-473. 
Ummah.M.K. 2010.Ekstraksi dan Pengujian Aktivitas Antibakteri Senyawa tanin pada Daun Belimbing Wuluh (Averrhoa bilimbi L.)(Kajian Variasi Pelarut), Skripsi, Kimia UIN Malang, Malang.

Romanoff, A. I. Dan A. J. Romanoff. 1963. The Avian Egg. Jhon Willey and Sons. Inc, New York.

Santoso, M. 2008. Inhibition of Fish Lipid Oxidation by the Extract of Indonesia Edible Plant Seed Melinjo. Japanese Society for Food Science and Technology . Kyoto, Jepang.

Sudaryani, T., 2003. Kualitas Telur. Jakarta: Penebar Swadaya.

Yuwanta, T. 2010. Telur dan Kualitas Telur. Gadjah Mada University Press, Yogyakarta. 